\title{
CFD SIMULATION OF A PILOT PLANT DELAYED COKING REACTOR USING AN IN-HOUSE CFD CODE
}

\author{
SIMULACIÓN DE UNA PLANTA PILOTO DE UN REACTOR DE COQUIZACIÓN \\ RETARDADA UTILIZANDO UN CÓDIGO INTERNO DE DINAMICA DE \\ FLUIDOS COMPUTACIONAL (CFD)
}

\section{SIMULAÇÃO DE UMA PLANTA PILOTO DE UM REATOR DE COQUEAMENTO RETARDADO APLICANDO UM CÓDIGO INTERNO DE FLUIDODINÂMICA COMPUTACIONAL (CFD)}

Fabian A. Díaz ${ }^{1 *}$, Arlex Chaves-Guerreroํ, Paola Gauthier-Maradei ${ }^{1}$, David Fuentes ${ }^{1}$, Alexander Guzmán² and Hector Picón².

'Universidad Industrial de Santander, Bucaramanga, Santander, Colombia ${ }^{2}$ Ecopetrol S.A - Instituto Colombiano del Petróleo, Km 7 vía Piedecuesta, Santander, Colombia.

e-mail: fabiandiazmateus@hotmail.com

\begin{abstract}
(Received: Jul. 16, 2016; Accepted: Nov. 15, 2017)

A simulation of a pilot plant delayed coking reactor was performed using an in-house computational fluid dynamics (CFD) code. The reactor was modeled as a three-phase dynamic system where the coke is the porous solid phase, the vacuum residue the liquid phase and the distillable product the gas phase. Equations of continuity, momentum, and energy proposed to describe the coking dynamic process where discretized employing the finite volume method and the domain was defined by a 2D structured axisymmetric grid. A PEA algorithm was developed to account for the drag between the fluid phases, and a modified SIMPLEC algorithm achieved the pressure-velocity coupling. The CFD simulator was programmed in $\mathrm{C}++$ code for Linux operating system; all the graphics were constructed in ParaView visualization platform. A full run of 12 hours and the cooling of the resulting coke bed for three different vacuum residues were simulated, the results were compared with experimental data and a good agreement was observed, the simulator demonstrated great potential to be scaled up to industrial level.
\end{abstract}

Keywords: Vacuum residue, Heavy oil, Numerical simulation, Computational Fluid Dynamics.

How to cite: Díaz, F. A., Chaves-Guerrero, A., Gauthier-Maradei, P., Fuentes, D., Guzmán, A., Picón, H. (2017). CFD simulation of a pilot plant Delayed Coking reactor using an In-House CFD code. CT\&F - Ciencia, Tecnología y Futuro, $7(1), 85-100$.

*To whom correspondence should be addressed 


\title{
RESUMEN
}

\begin{abstract}
TT na simulación de un reactor piloto de coquización retardada fue realizada empleando un código propio de dinámica de fluidos computacional (CFD). El reactor fue modelado como un sistema dinámico de tres fases donde el coque es una fase sólida porosa, el fondo de vacío es la fase líquida y los productos destilables son la fase gaseosa. Los balances de continuidad, momento y energía propuestos para describir la dinámica del proceso de coquización fueron discretizados mediante el método de los volúmenes finitos sobre una malla axisimétrica de dos dimensiones. Un algoritmo tipo PEA fue desarrollado para describir el arrastre entre las fases fluidas y un algoritmo SIMPLEC modificado llevó a cabo el acoplamiento entre la presión y la velocidad. El simulador de CFD fue programado en lenguaje C ++ para sistema operativo tipo Linux; todos los gráficos fueron construidos en la plataforma de visualización Paraview. Una corrida completa de 12 horas y el posterior enfriamiento de la cama de coque obtenida para tres fondos de vacío fue simulada, los resultados fueron comparados con datos experimentales y un buen acuerdo fue encontrado, el simulador demostró gran potencial para ser escalado a nivel industrial.
\end{abstract}

Palabras clave: Fondos de vacío, Petróleo pesado, Simulación numérica, Dinámica de Fluidos Computacional.

\section{RESUMO} oi realizada uma simulação de uma planta piloto de um reator de coqueamento retardado aplicando
um código interno de fluidodinâmica computacional (CFD). O reator foi modelado como um sistema
dinâmico de três fases, estando o coque em fase sólida, o resíduo de vácuo em fase líquida, e os
destiláveis em fase gasosa. As equações de continuidade, de momento e de energia propostas para descrever
o processo de coquemento dinâmico foram discretizadas utilizando o método dos volumes finitos, e a área
foi definida por uma grade de eixo de simetria estruturada em 2D. Foi desenvolvido um algoritmo PEA para
representar o arrasto entre as fases fluidas, e um algoritmo SIMPLEC modificado atingiu o acoplamento
pressão-velocidade. O simulador CFD foi programado em código C++ para o sistema operacional Linux.
Todos os gráficos foram construídos em uma plataforma ParaView. Simulando a operação de 12 horas e
o arrefecimento do leito de coque resultante para três resíduos de vácuo diferentes, os resultados foram
comparados com os dados experimentais e foi observado uma boa correlação, o simulador mostrou grande
potencial de ser escalado no nível industrial

Palavras-chave: Resíduo de vácuo, Petróleo pesado, Simulação numérica, Dinâmica Computacional de Fluidos. 


\section{INTRODUCTION}

The delayed coking process is a purely thermal process where a heavy residual oil is converted into coke, liquids, and gases at temperatures above $400^{\circ} \mathrm{C}$. At industrial level, the residue is heated up in a furnace and rapidly transferred into a vertical drum; the word "delayed" comes from the attempt of delaying the formation of coke inside the furnace to be taking only inside the drum. The process is semi-continuous because when one drum is full of coke, the feed switches to a second drum while the first one is discharged, and so on.

The delayed coking process is the preferred choice of refiners for the thermal conversion of petroleum residue, due to the flexibility of handling different types of residues (Rana, Samano, Ancheyta, \& Diaz, 2007) and their higher economic benefits comparing it to other processes for thermal conversion of heavy oil (Vartivariam \& Andrawis, 2006).

Ellis \& Hardin (1993) presented a detailed description of the process for coke formation inside a drum. However, an attempt to numerically simulate this unsteady process has not been submitted in the literature, and most of the work focuses on the coking furnace. With an in house CFD code, Souza, Matos, Guirardello \& Nunhez (2006) performed a $2 \mathrm{D}$ axisymmetric simulation of the pipes of a coking furnace where the yield of coke, liquid, and gas is estimated. However, the coke was not deposited inside the pipe walls. Also, Zhang et al. (2015) performed a numerical simulation of the pipes of a coking furnace but in $3 \mathrm{D}$ with a CFD commercial code. In this simulation, the coke was neither deposited inside the pipe walls.

To the best of our knowledge, a CFD simulation of a delayed coking reactor has not been presented in the literature. Nevertheless numerous simulators based on correlations or statistical models have been shown in the literature; some of the most recognized correlations are Gary \& Handwerk (1975); Castiglioni (1983); Maples (2000); Zambrano (2001); Volk, Wisecarver \& Sheppard (2002); Pushpalayari (2004) and Ghashghaee (2015). These models provide an estimate of the yield of coke, liquids, and gases and are based on the assumption that the process is at steady state. An interesting comparison of these correlation models for delayed coking simulation can be found in Ancheyta et al. (2013). After a validation with experimental data, they concluded that the correlation of Volk, Wisecarver $\&$ Sheppard (2002) provided the higher accurate results as it takes into account not only the properties of the feed but the operating conditions as well. Of course, in this investigation, the correlation of Ghashghaee (2015) was not taken into account.

Several simulation models merely based upon chemical kinetics can also be found in the literature: Bozzano \& Dente (2005), Zhou, Chen \& Li (2007) and Borges, Mendes \& Alves (2015). These models are based on the assumption that the process is at steady state providing an estimate of the yield of coke, liquids, and gases according to the properties of the feed and the operating conditions; however, the composition of the liquid is relatively more defined as it is divided into pseudo-components. An even more detailed characterization of the feed and the products is presented in the simulation by Tian, Shen \& Liu (2012a, 2012b) based on structured oriented lumping (SOL). With this method, the feed and the products are characterized at molecular level offering up to 7000 pseudo-components. This simulation is also based on the assumption that the process is at steady state.

The delayed coking process is inherently dynamic, and the filling of an industrial drum with coke usually takes 12 hours. The simulation of this process is a very complex task since at least three phases are shown, and the coke is a porous medium with a porosity that varies in space and time. A dynamic simulation of a $12 \mathrm{~h}$ run is computationally extremely expensive since the time stage is necessarily a fraction of a second, as described in this work.

A CFD simulation of the delayed coking pilot plant reactor from ECOPETROL - ICP (Colombian Institute of Petroleum, ECOPETROL) is performed in this work; the mathematical model is based on unsteady continuity, momentum and energy balances for the three phases (gas, liquid and solid) which are numerically solved using CFD techniques. An in-house CFD code was developed basically for two reasons; the mathematical approach for the formation and accumulation of coke could not be programmed in a commercial CFD code, as such codes consider the porous media like a zone or a volume rather than a solid phase. Additionally, the 
mathematical models used to solve the equations hugely increase the speed of the calculations when compared with the commercial software.

A twelve hours run for three vacuum residues were simulated. The cooling of the coke bed produced at the end of the twelve hours is also simulated. The only experimental data available to validate the simulations is the quantity of coke produced in a run, thus, the properties of the coke bed calculated in the simulations were validated with experimental data available in the literature.

\section{THEORETICAL FRAMEWORK}

A scheme of the reactor from the delayed coking pilot plant at ICP is shown in Figure 1. The reactor consists of a pipe with walls heated up by electrical resistances; given the geometry, a 2D axisymmetric grid can simulate the entire physical geometry of the reactor. The feed (vacuum residue) enters at the bottom while the distillable products exit at the top, the coke product remains inside the reactor and it is removed at the end of the run. The complete set of operating conditions used in the experimental procedures and the simulations is shown in Table 1

Table 1. Operating conditions for the delayed coking reactor

\begin{tabular}{cc|}
\hline Temperature of the walls & $510^{\circ} \mathrm{C}$ \\
\hline Temperature of the feed & $370^{\circ} \mathrm{C}$ \\
\hline Feed mass rate & $5 \mathrm{~g} / \mathrm{min}$ \\
\hline Reactor diameter & $2.5 \mathrm{NPS}, \mathrm{SCH} 40$ \\
\hline Reactor length & $569.2 \mathrm{~mm}$ \\
\hline Operating pressure & $1 \mathrm{~atm}$. \\
\hline Run length & $12 \mathrm{hours}$ \\
\hline
\end{tabular}

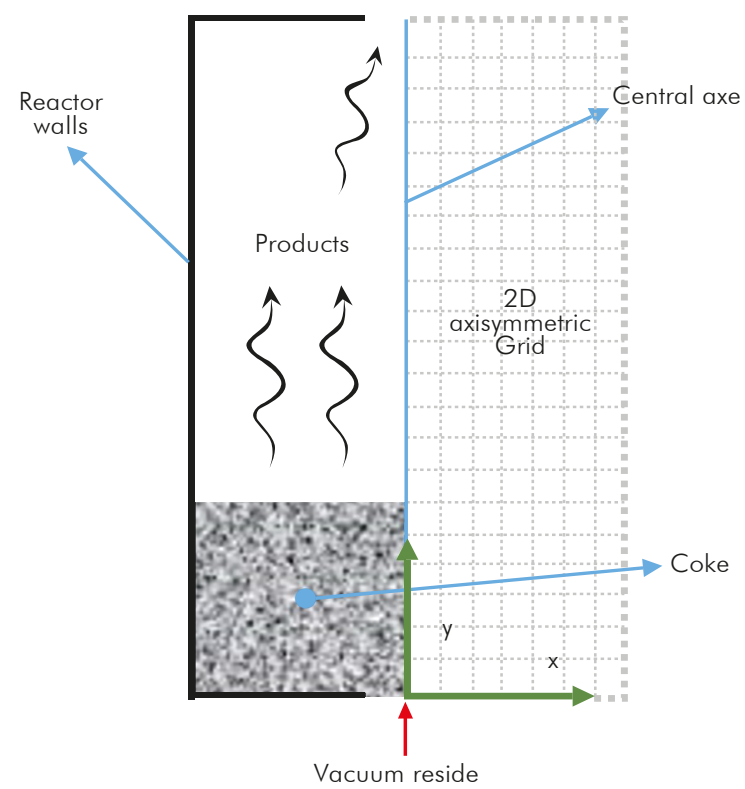

Figure 1. Scheme of the delayed coking reactor at ICP

The kinetic model used in the simulation of the delayed coking reactor is taken from Diaz et al. (2015) and it can be seen on Eq. 1. It consists of a simple kinetic model where the vacuum residue decomposes into coke and distillables, and the reaction mechanism gradually changes from first to second order depending on the temperature. At lower temperatures, the reaction is modeled as a first order reaction; as the temperature rises, the order of the reaction changes to 1.5 order and second order for the higher temperatures. The kinetic parameters for all the mechanisms and the temperatures where the mechanism changes can be seen on Table 2 .

Three different vacuum residues were employed in the simulations, and their main physical properties can be seen in Table 3. Detailed physical properties of the vacuum residues and the physical properties of the coke and the distillables can be found in Diaz (2016).

$V R \stackrel{k}{\rightarrow}$ Coke + Distillables

(1)

Table 2. Kinetic parameters used to model the reactions

\begin{tabular}{|c|c|c|c|c|c|c|c|c|}
\hline \multirow{2}{*}{ VR } & \multicolumn{2}{|c|}{ First order } & \multirow{2}{*}{$\begin{array}{l}\text { Change } \\
\text { temp. } \\
\left({ }^{\circ} \mathrm{C}\right)\end{array}$} & \multicolumn{2}{|c|}{1.5 order } & \multirow{2}{*}{$\begin{array}{l}\text { Change } \\
\text { temp. } \\
\left({ }^{\circ} \mathrm{C}\right)\end{array}$} & \multicolumn{2}{|c|}{ Second order } \\
\hline & $\mathrm{Ea}(\mathrm{J} / \mathrm{mol})$ & $\mathrm{Kf}(1 / \mathrm{s})$ & & $\mathrm{Ea}(\mathrm{J} / \mathrm{mol})$ & $\mathrm{Kf}(1 / \mathrm{s})$ & & $\mathrm{Ea}(\mathrm{J} / \mathrm{mol})$ & $\mathrm{Kf}(1 / \mathrm{s})$ \\
\hline 1 & $2.6577 E+05$ & $7.5386 E+15$ & 500 & $3.6297 E+05$ & $3.4453 E+22$ & 564.8 & $1.6763 E+05$ & $3.1806 E+10$ \\
\hline 2 & $1.2495 E+05$ & $1.7831 E+06$ & 478.9 & $2.5498 \mathrm{E}+05$ & $3.7711 \mathrm{E}+15$ & 560.8 & $2.0477 E+05$ & $5.1982 E+12$ \\
\hline 3 & $1.1045 \mathrm{E}+05$ & $7.8408 \mathrm{E}+04$ & 487.8 & $3.0287 E+05$ & $3.3909 E+18$ & 570.1 & $1.8316 \mathrm{E}+05$ & $2.1660 E+11$ \\
\hline
\end{tabular}


Table 3. Main physical properties of the vacuum residues used in the simulations

\begin{tabular}{|c|c|c|c|}
\hline Vacuum residue & 1 & 2 & 3 \\
Dens- $15^{\circ} \mathrm{C}[\mathrm{g} / \mathrm{ml}]$ & 0.999 & 1.056 & 1.05 \\
\hline API & 9.9 & 2.3 & 3.26 \\
\hline CCR [\%wt] & 18.4 & 32.6 & 32 \\
\hline Saturates [\%wt] & 16.7 & 13.7 & 5.14 \\
\hline Aromatics [\%wt] & 45.34 & 41.89 & 29.71 \\
\hline Resins [\%wt] & 30.62 & 17.18 & 35.71 \\
\hline Asphaltenes [\%wt] & 7.34 & 27.23 & 29.2 \\
\hline
\end{tabular}

For the development of the governing equations, a series of assumptions were made in order to simplify the model without significantly affecting the results, these assumptions are:

- The model is $2 \mathrm{D}$ axisymmetric orbiting the central axe.

- The system is composed of two fluid phases: liquid (vacuum residue) and gas (distillables) and one solid phase (coke) which is modeled as a porous solid that accumulates in time.

- The liquid is the primary phase (continuous), and the gas is the secondary (dispersed) and can be modeled in the eulerian approach.

- The chemical reaction can be modeled by the thermal decomposition (pyrolysis) of vacuum residue into distillables and coke.

- Due to the low velocities of the phases, the fluid flow can be considered laminar.

- The coke does not have movement; it remains still at the place where it is formed The low velocity of the feed creates a very thin layer of vacuum residue above the coke bed, the coke forms in that layer or within the coke bed; for that reason the movement of the coke can be discarded.

- The coke product is of a shot type, which means that it is formed as an agglomeration of small spherical particles and can be modeled as a packed bed. The momentum loss through the coke bed is calculated in this way. Shot coke obtained experimentally shows particles with a typical diameter of $1 \mathrm{~mm}$.

- The porous medium (coke bed) is isotropic (homogenous).

- The effects of pressure and viscous heating on energy balances are discarded.
- The porosity of the coke bed is completely effective, which means that all the pores are interconnected.

- Radiation is discarded from the energy equations since the temperature is moderate and the medium is opaque and hardly transmitting radiation.

The continuity equation for the vacuum residue $(R)$ and distillable $(D)$ phase is presented in Eq. 2.

$\frac{\partial\left(\gamma \alpha_{\mathrm{n}} \rho_{\mathrm{n}}\right)}{\partial t}+\nabla \cdot\left(\gamma \alpha_{n} \rho_{n} \vec{v}_{n}\right)=-\gamma \alpha_{n} \rho_{n} \Gamma_{n}$

Where $n=R, D$

The continuity equation for the coke phase (C) is presented on Eq. 3.

$\frac{\partial\left(\alpha_{\mathrm{C}} \rho_{\mathrm{C}}\right)}{\partial t}+\gamma \alpha_{R} \rho_{R} \Gamma_{C}$

Continuity equations can also be called volume fraction equations. If the porosity of the coke bed is completely effective, it can be calculated as the space left by the coke volume fraction (Eq. 4).

$$
\gamma=1-\alpha_{C}
$$

The momentum equation for the vacuum residue $(R)$ and distillable $(D)$ phase is shown in Eq. 5.

$$
\begin{aligned}
\frac{\partial\left(\gamma \alpha_{n} \rho_{\mathrm{n}} \vec{v}_{n}\right)}{\partial t} & +\nabla \cdot\left(\gamma \alpha_{n} \rho_{n} \vec{v}_{n} \vec{v}_{n}\right) \\
& =-\gamma \alpha_{n} \nabla \cdot p+\nabla^{2} \cdot\left(\gamma \alpha_{n} \mu_{n} \vec{v}_{n}\right)+\gamma \alpha_{n} \rho_{n} \vec{g}+\gamma \mathrm{K}_{\mathrm{mn}}\left(\vec{v}_{m}-\vec{v}_{n}\right) \quad(5) \\
& -\alpha_{n} \vec{v}_{n}\left(\frac{\gamma^{2} \mu_{n}}{\varepsilon}+\frac{\gamma^{3} C_{2} \rho_{n}\left|\vec{v}_{n}\right|}{2}\right)
\end{aligned}
$$

Where $n, m=R, D$ and $m \neq n$

The coke phase does not have momentum equation. The second last term in Eq. 5 corresponds to the drag between the fluid phases; the last term corresponds to the momentum loss through the coke bed.

In this work, a detailed calculation of temperature is desired, since the cooling of the coke bed formed at the end of the run will be simulated. For that reason, energy balances are proposed for each phase as if they were not in thermal equilibrium. The energy equation for the vacuum residue $(R)$ and distillable $(D)$ phase is shown in Eq. 6.

$$
\begin{aligned}
\frac{\partial\left(\gamma \alpha_{n} \rho_{n} C_{P, n} T_{n}\right)}{\partial t} & +\nabla \cdot\left(\gamma \alpha_{n} \rho_{n} C_{P, n} \vec{v}_{n} T_{n}\right) \\
& =\nabla^{2} \cdot\left(\gamma \alpha_{n} k_{n} T_{n}\right)+\gamma \alpha_{n} \rho_{n} \Gamma_{n} \Delta H_{\mathrm{n}}+\gamma H_{m n}\left(T_{m}-T_{n}\right) \\
& +\alpha_{n} H_{C n}\left(T_{C}-T_{n}\right)
\end{aligned}
$$


Where $n, m=R, D$ and $m \neq n$

The energy equation for the coke $(C)$ phase is shown in Eq. 7.

$\frac{\partial\left(\alpha_{C} \rho_{C} C_{P, C} T_{C}\right)}{\partial t}+\nabla^{2} \cdot\left(\gamma \alpha_{C} k_{C} T_{C}\right)+\alpha_{R} H_{C R}\left(T_{R}-T_{C}\right)+\alpha_{D} H_{C D}\left(T_{D}-T_{C}\right)$

The momentum exchange coefficients $\left(K_{m n}\right)$ were calculated with the symmetric model (ANSYS, 2014); the symmetric model is recommended where the secondary phase becomes primary phase in different places of the domain, in this simulation the distillables are primary phase above the coke bed and secondary phase inside of it.

The permeability $(\varepsilon)$ and the inertial resistance factor $\left(C_{2}\right)$ are calculated with the correlations from Ergun (1952) which are developed for flow through packed beds. The fluid-fluid heat transfer coefficients $\left(H_{m n}\right)$ are calculated with Tomiyama's correlation (Tomiyama, 1998) which is appropriate for the low Reynolds flow. The fluid-solid heat transfer coefficients $\left(H_{C R}, H_{C D}\right)$ are calculated with the correlations from Wakao and Kaguei (1982) also recommended for the low Reynolds flow.

The equations were discretized by the finite volume method, and the pressure-velocity coupling was achieved using the SIMPLEC algorithm (Van Doormal \& Raithby, 1984). The procedure proposed by Patankar \& Spalding (1972), to obtain the pressure correction equation through an arrangement of continuity and momentum equations, was used in this work.

As the momentum exchange (drag) between the fluid phases is considered in the momentum equations, the partial elimination algorithm (PEA) (Spalding \& Markatos, 1983) was used to avoid convergence issues caused by the coupling of the momentum equations. To avoid the famous "pressure checkerboard" or unrealistic pressure oscillations caused by the interpolation of the pressure, a staggered grid was used for the solution of the momentum equations.

Continuity, momentum, and energy equations were solved with a Gauss-Seidel (GS) procedure. This method performs a sweeping through all the volumes of the grid, solving an equation of the form of Eq. 8 to obtain the value of the variable in the volume. One advantage of the GS method is that the values of the variables can be controlled and modified directly on the volume. In multiphase models, this is very advantageous because, if in a portion of the domain the volume fraction of a phase is zero, the value of the other variables (velocities, temperatures, etc.) can be set to zero and the rest of the domain can be solved according to those values. That method provided a huge increase in the speed of the calculations.

$\phi_{C V}=\frac{\sum a_{N B} \phi_{N B}+\hat{S}_{C V}}{a_{C V}}$

If the GS method is over-relaxed, it becomes the SOR (Successive Over-Relaxation) method. A relaxation factor among $1-2$ is used to accelerate convergence. The pressure correction equation was solved using a SOR method with a relaxation factor among 1.93-1.94.

Two grid sizes $(7 \times 126,14 \times 252)$ were simulated at single-phase steady state and the velocities obtained were compared. The results showed that 882 (7x126) volumes are enough to calculate proper velocity profiles. The Courant number was employed to determine the appropriate time step size. The Courant number was calculated with the Eq. 9.

Courant $=\frac{v_{x} \Delta t}{\Delta x}+\frac{v_{y} \Delta t}{\Delta y}$

A Courant number below 1 is recommended for explicit discretization, while implicit discretization (as in this work) can use values above 1 . In order to assure a Courant number around 1 , the time step was set at 0.01 seconds. The detailed procedure to obtain the optimum mesh size and time step size can be found in Díaz (2016).

The programming code was written in $\mathrm{C}++$ language and compiled in a Linux operating system; the $\mathrm{C}$ compiler employed was the Intel System Studio. The graphics were constructed in the ParaView ${ }^{\circledR}$ visualization platform. A full run of 12 hours was simulated for three vacuum residues and it took 4 weeks of continuous work in an Intel I7-4960X processor to complete the simulations. 


\section{RESULTS}

\section{Simulation of the 12 hours run}

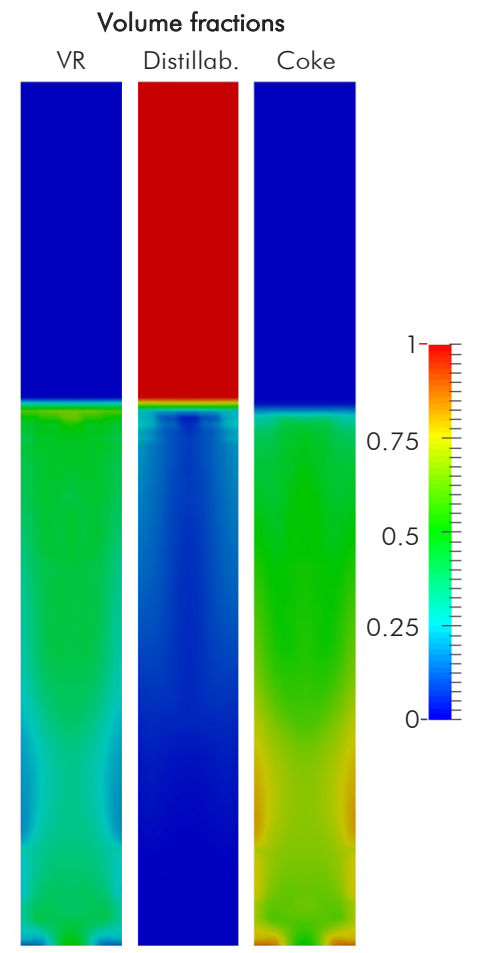

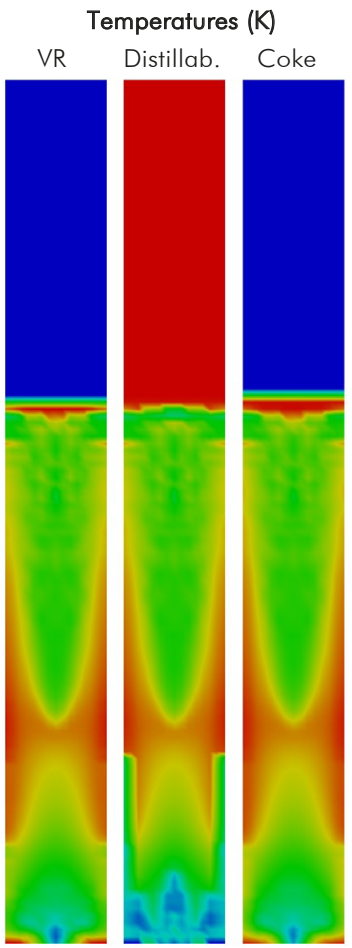
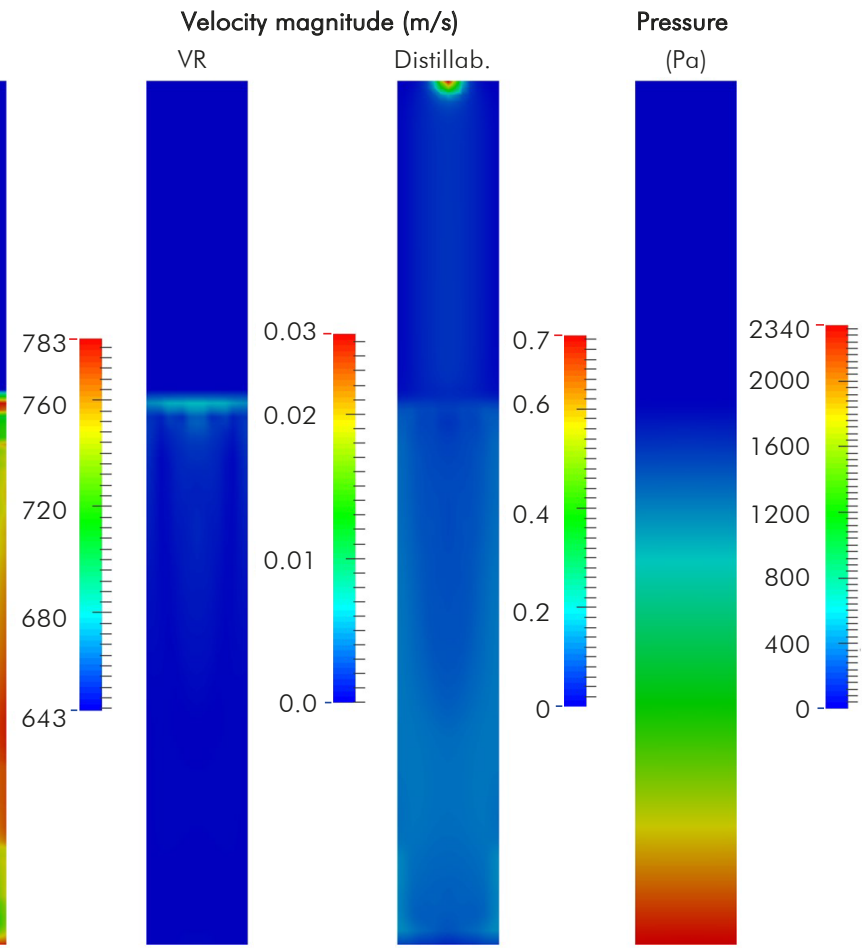

Figure 2. Contours of volume fraction, temperature, velocity magnitude and pressure obtained in the simulation of the 12 hours run with vacuum residue 1.
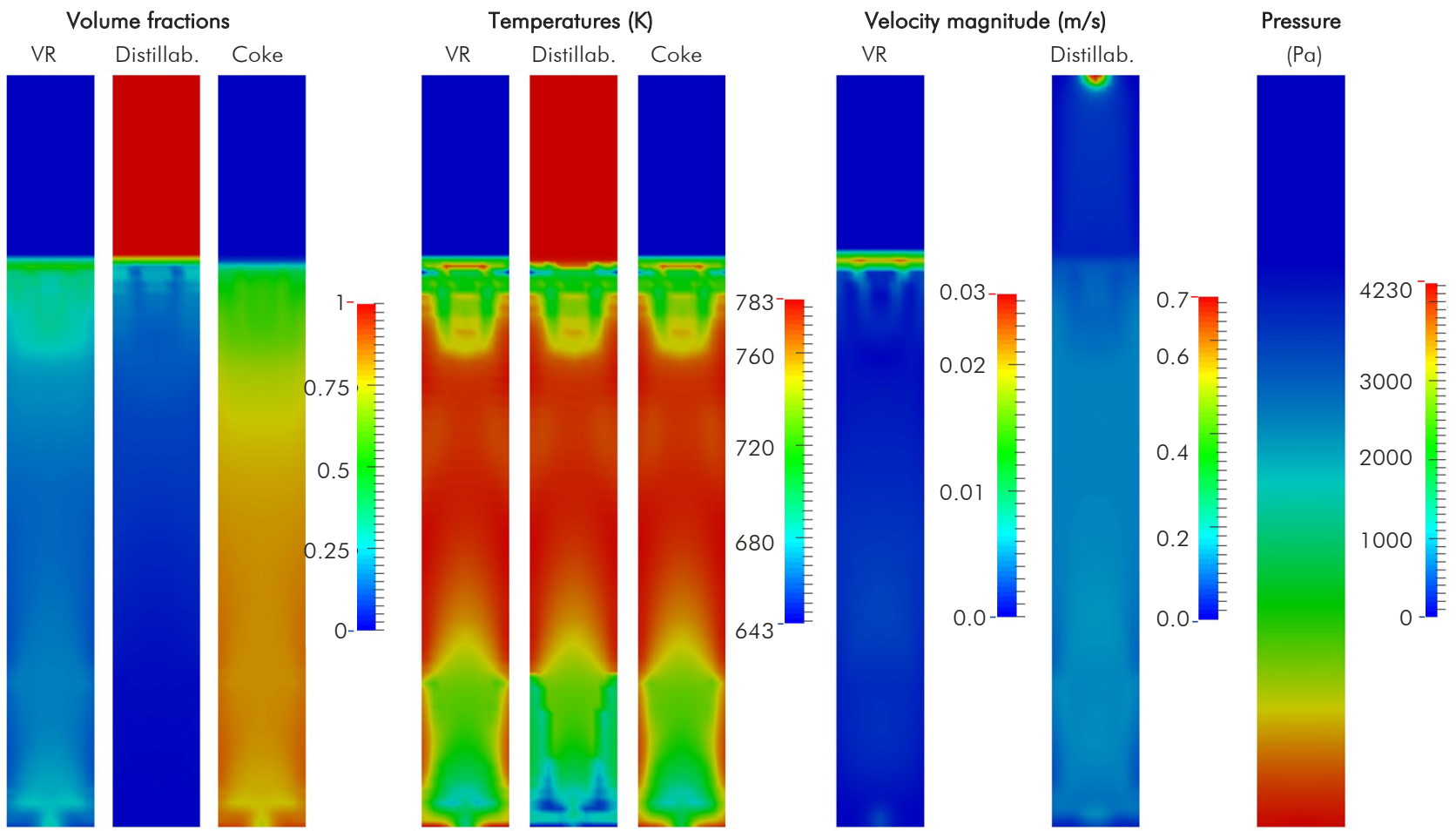

Figure 3. Contours of volume fraction, temperature, velocity magnitude and pressure obtained in the simulation of the 12 hours run with vacuum residue 2 . 


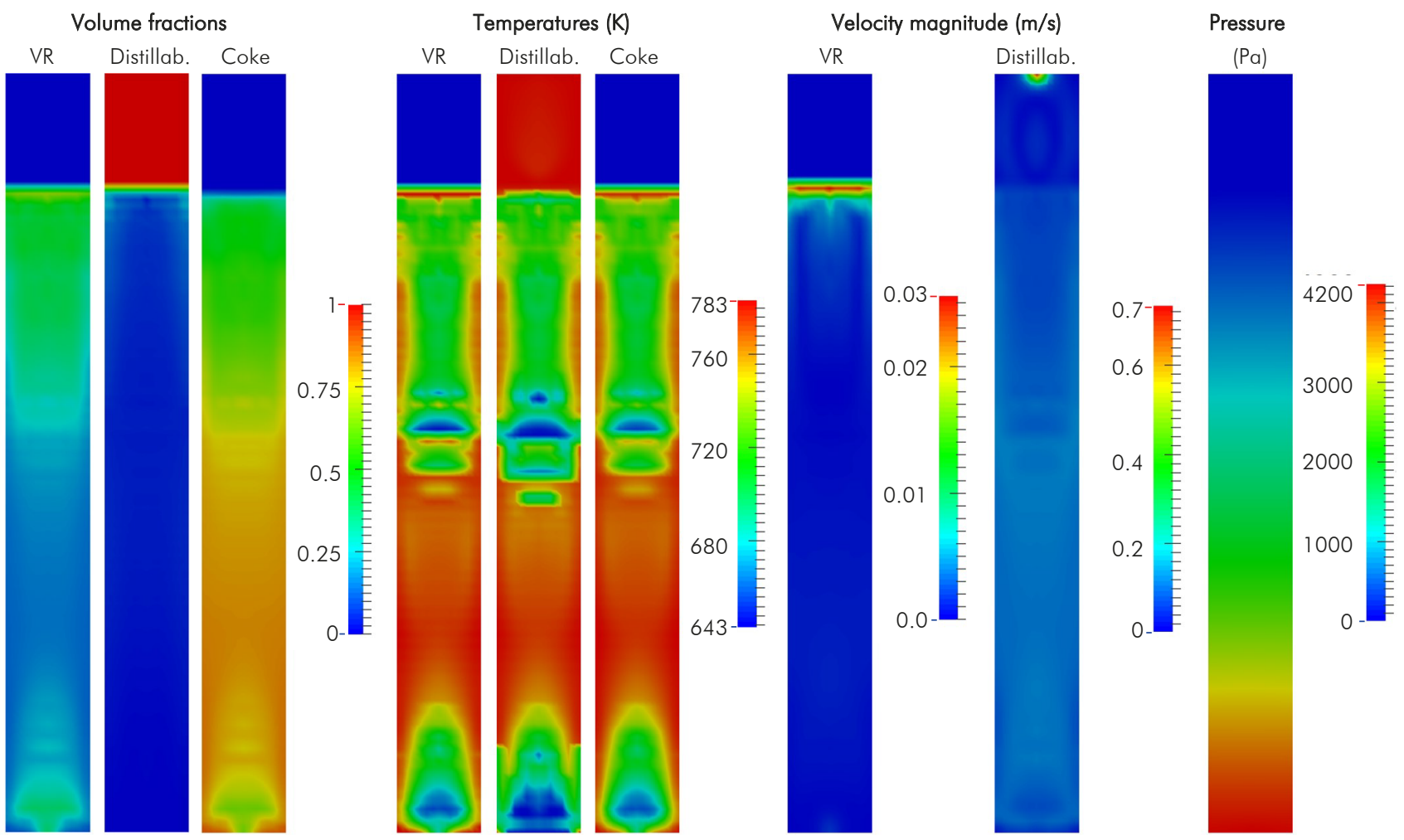

Figure 4. Contours of volume fraction, temperature, velocity magnitude and pressure obtained in the simulation of the 12 hours run with vacuum residue 3.

Figures $2-4$ show how the volume fraction of the phases changes in every direction and how the volume fraction of coke tends to be higher at the bottom and on the walls of the reactor. To achieve a more detailed analysis of the evolution of the volume fractions, Figures $5-7$ were depicted where the volume fraction traced at the center of the reactor were plotted against the reactor height.

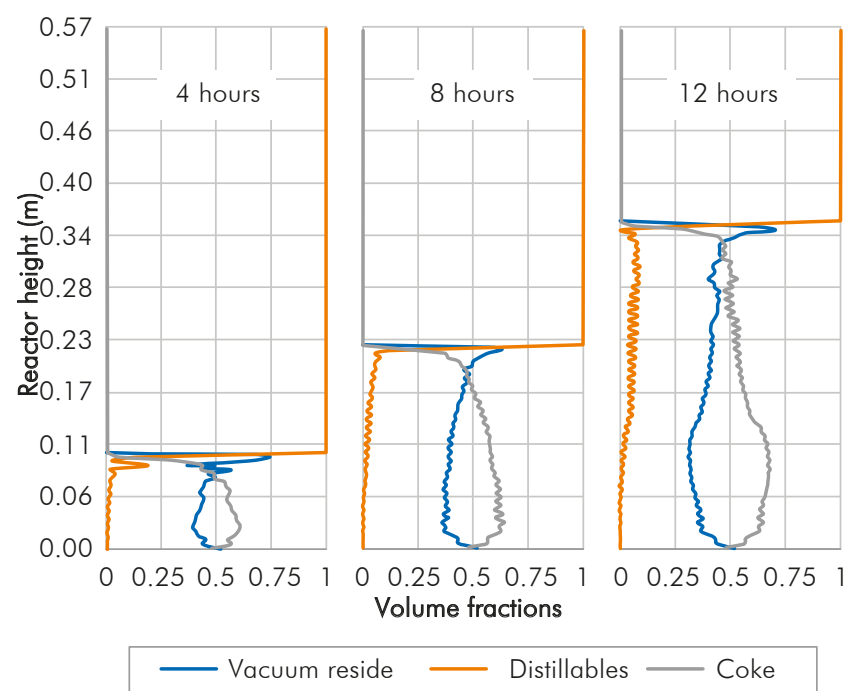

Figure 5. Volume fractions obtained in the simulation at 4, 8 and 12 hours of run with vacuum residue 1 .
Figures $8-10$ show the porosity of the coke bed calculated in the simulations and traced at the center and on the wall of the reactor at different times of run. On this figures, it can be seen how the porosity is lower on the walls than at the center of the delayed coking reactor and how the porosity decreases with the height of the coke bed.

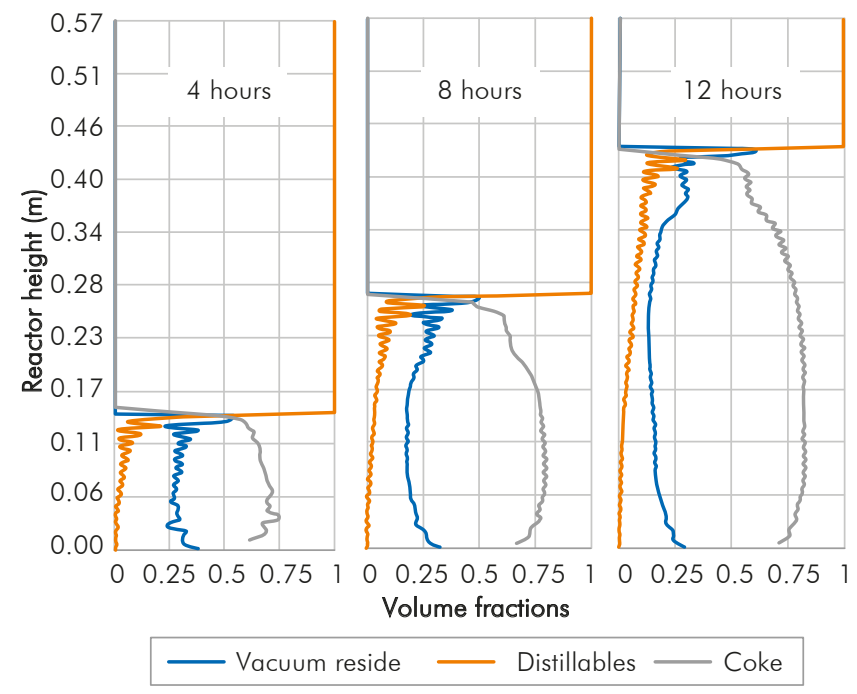

Figure 6. Volume fractions obtained in the simulation at 4, 8 and 12 hours of run with vacuum residue 2 . 


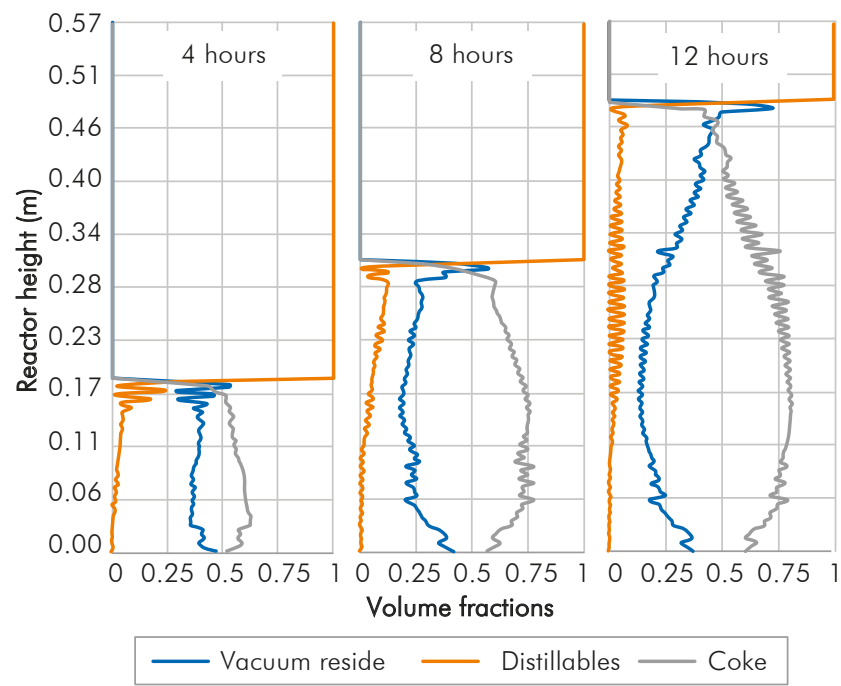

Figure 7. Volume fractions obtained in the simulation at 4,8 and 12 hours of run with vacuum residue 3 .

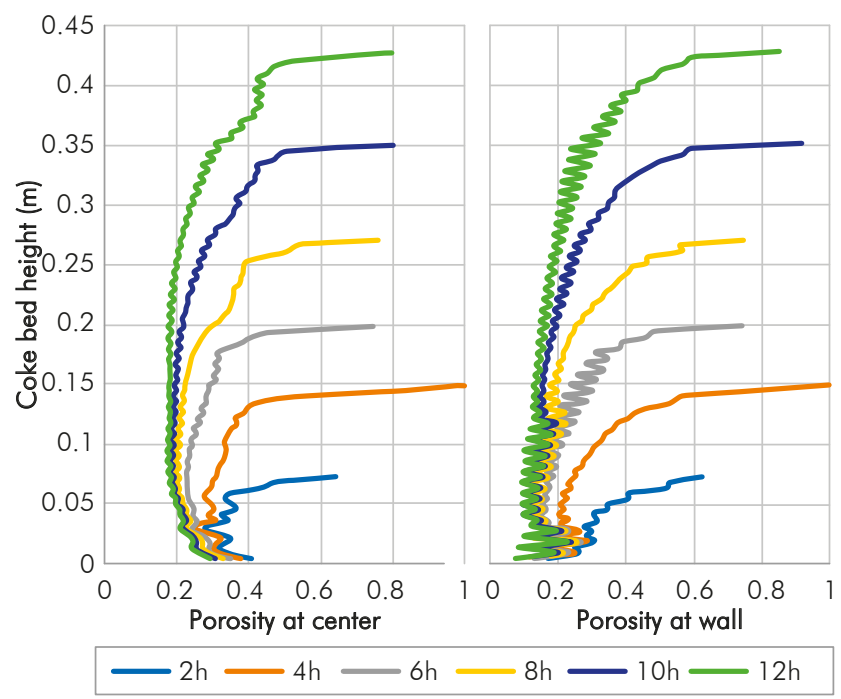

Figure 9. Porosity obtained in the simulation at the center and the wall of the reactor at different times of run with vacuum residue 2 .

Figure 11 shows the evolution of the coke bed height in time for the three vacuum residues. Vacuum residue 3 produces the highest coke bed while vacuum residue 1 produces the lowest one. This is corresponding to the quantity of coke produced in the kinetic experiments (Díaz et al., 2015) where vacuum residue 1 produced the smallest quantity of coke and vacuum residue 3, the largest.

Figure 12 shows the pressure drop calculated in the simulations during the run- time for the three vacuum residues. As it is expected, the pressure drop for the vacuum residue 1 is the smaller one since it generates the lower and more porous coke bed (See Table 4).

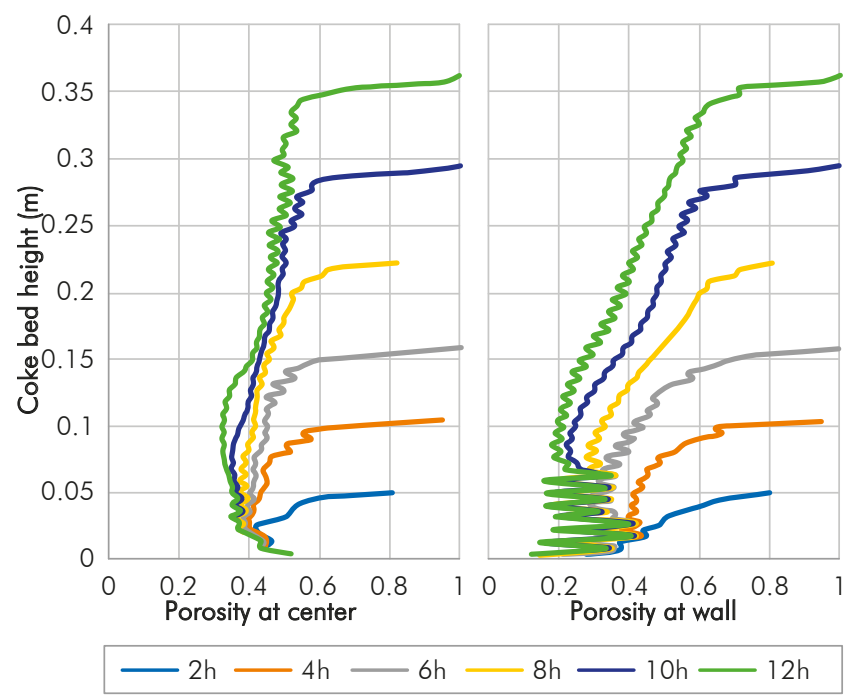

Figure 8. Porosity obtained in the simulation at the center and the wall of the reactor at different times of run with vacuum residue 1.

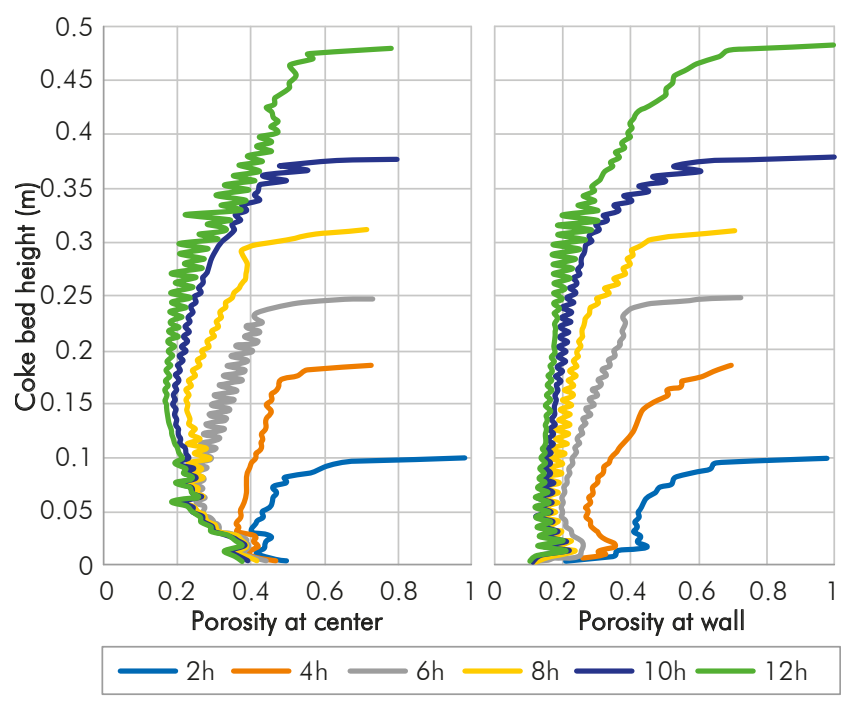

Figure 10. Porosity obtained in the simulation at the center and the wall of the reactor at different times of run with vacuum residue 3.

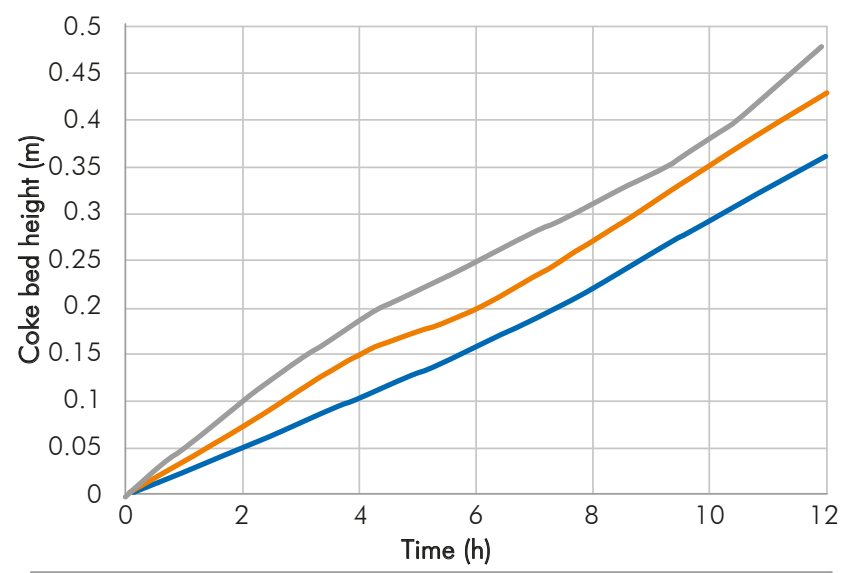

- Vacuum residue 1 - Vacuum residue 2 - Vacuum residue 3

Figure 11. Coke bed height calculated in the simulations as function of time. 
Table 4. Coke bed height and porosities obtained in the simulations.

\begin{tabular}{|ccccc|}
\hline Vacuum residue & 1 & 2 & 3 \\
\hline Coke bed height $(\mathrm{m})$ & 0.3614 & 0.4292 & 0.4834 \\
\hline $\begin{array}{c}\text { volume-averaged } \\
\text { porosity at wall }\end{array}$ & 0.3872 & 0.2211 & 0.2577 \\
\hline $\begin{array}{c}\text { volume-averaged } \\
\text { porosity at center }\end{array}$ & 0.4501 & 0.2526 & 0.3027 \\
\hline $\begin{array}{c}\text { volume-averaged } \\
\text { porosity of the coke bed }\end{array}$ & 0.4351 & 0.2416 & 0.29 \\
\hline
\end{tabular}

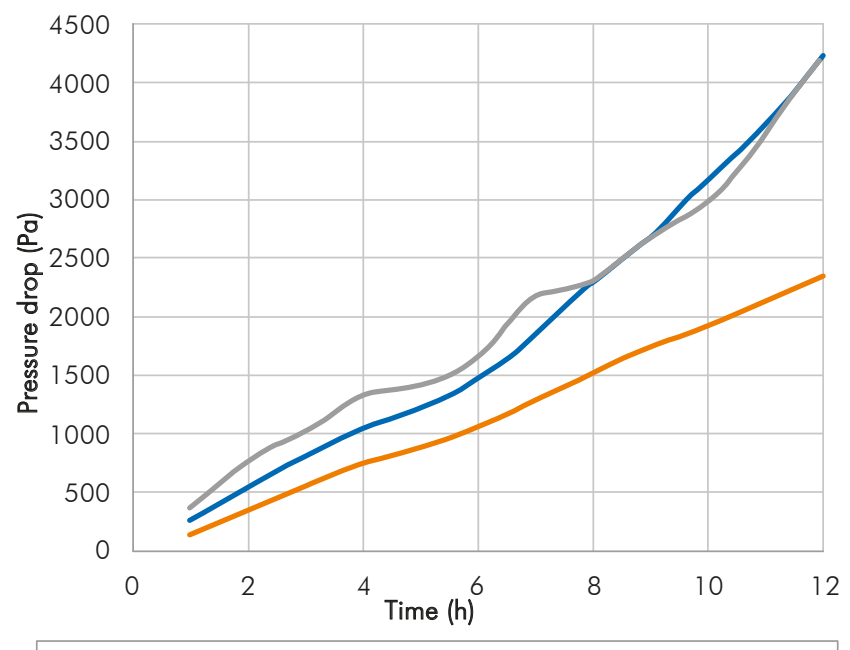

- Vacuum residue 1 - Vacuum residue 2 - Vacuum residue 3

Figure 12. Pressure drop calculated in the simulations as function of time.

Table 5. Comparison of the coke weight percentage obtained in the simulations with the experimental values.

\begin{tabular}{|c|c|c|c|}
\hline Vacuum residue & 1 & 2 & 3 \\
Experimental (ICP) & $21.59 \%$ & $35.52 \%$ & $36.57 \%$ \\
\hline Simulation & $21.43 \%$ & $33.75 \%$ & $35.69 \%$ \\
\hline \%Deviation & $0.74 \%$ & $4.98 \%$ & $2.41 \%$ \\
\hline
\end{tabular}

\section{Simulation of the coke bed cooling}

When the 12 hours- run is completed during the operation of the pilot plant at ICP, the flow inlet valves are closed and the reactor remains with the furnace turned on for about 20 minutes to decompose the remaining vacuum residue. Then, the furnace is turned off and the coke bed is cooled down with a flow of about $124 \mathrm{~cm}^{3} / \mathrm{s}$ of nitrogen. The mathematical model to simulate the cooling of the coke bed is the same shown in Eq. 2 - 7; only two modifications are required. First, the vacuum residue phase is switched for a new nitrogen phase. Second, the thermal boundary condition in the walls is switched from a constant temperature (Dirichlet boundary condition) to a gradient in the normal direction equal to zero (Neumann boundary condition). The contours of the temperature obtained in the simulation of the cooling of the coke bed for the three vacuum residues are shown in Figures 13 - 15. Figure 16 shows the medium temperature obtained in the simulations of the cooling of the coke bed for the three vacuum residues. Figures $13-16$ show that vacuum residue 1 requires 30 minutes to cool down to a temperature of about $40^{\circ} \mathrm{C}$, while vacuum residue 2 requires 60 minutes and vacuum residue 3 requires 50 minutes to reach the same final temperature.

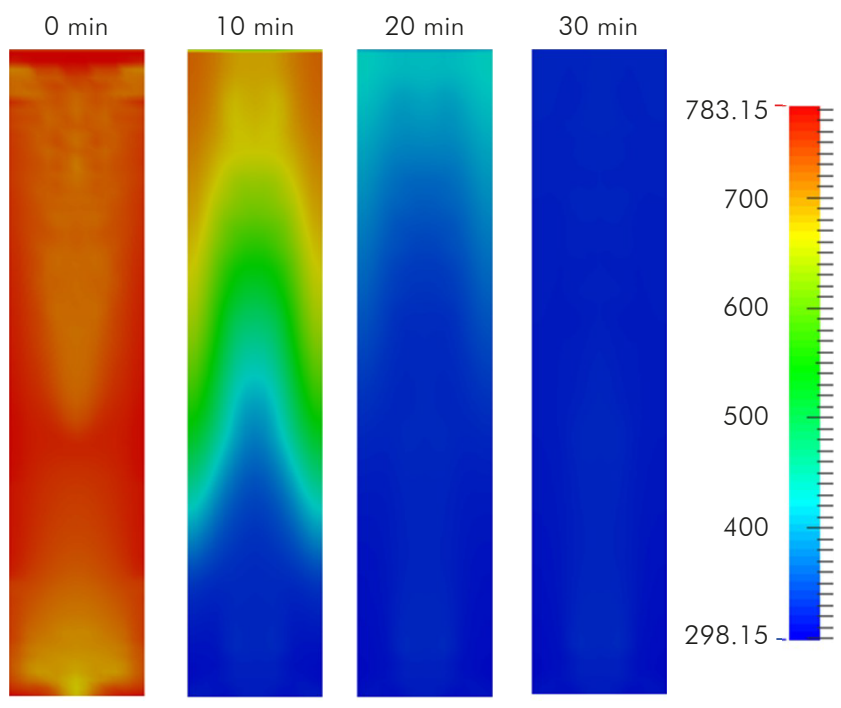

Figure 13. Contours of temperature $(K)$ obtained in the simulation of the cooling of the coke bed of vacuum residue 1 .
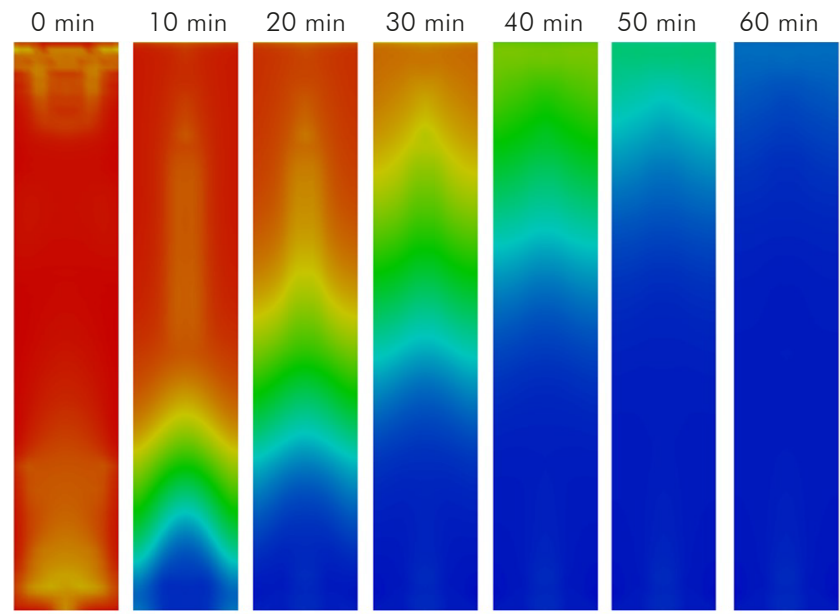

298.15

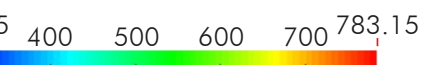

Figure 14. Contours of temperature $(K)$ obtained in the simulation of the cooling of the coke bed of vacuum residue 2 . 


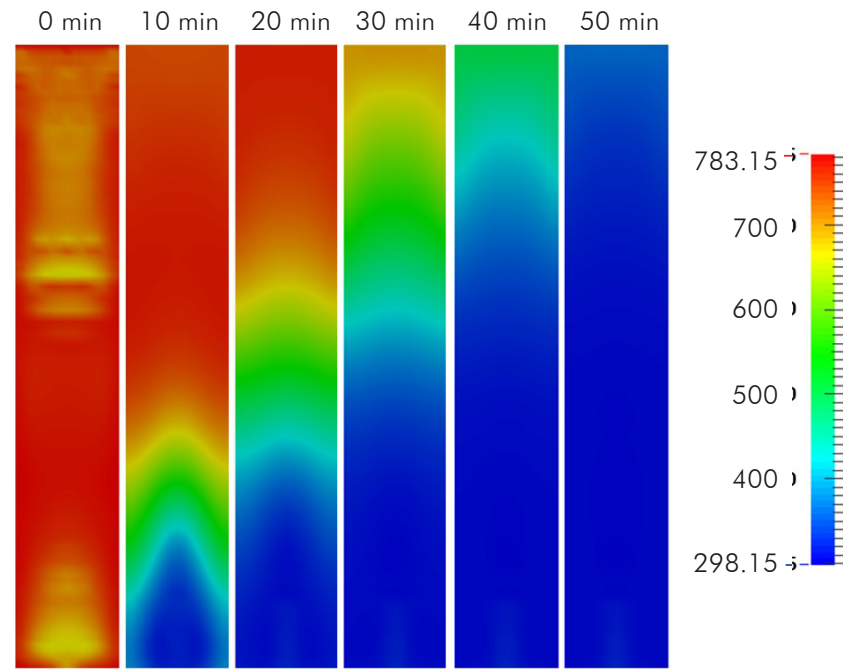

Figure 15. Contours of temperature $(K)$ obtained in the simulation of the cooling of the coke bed of vacuum residue 3 .

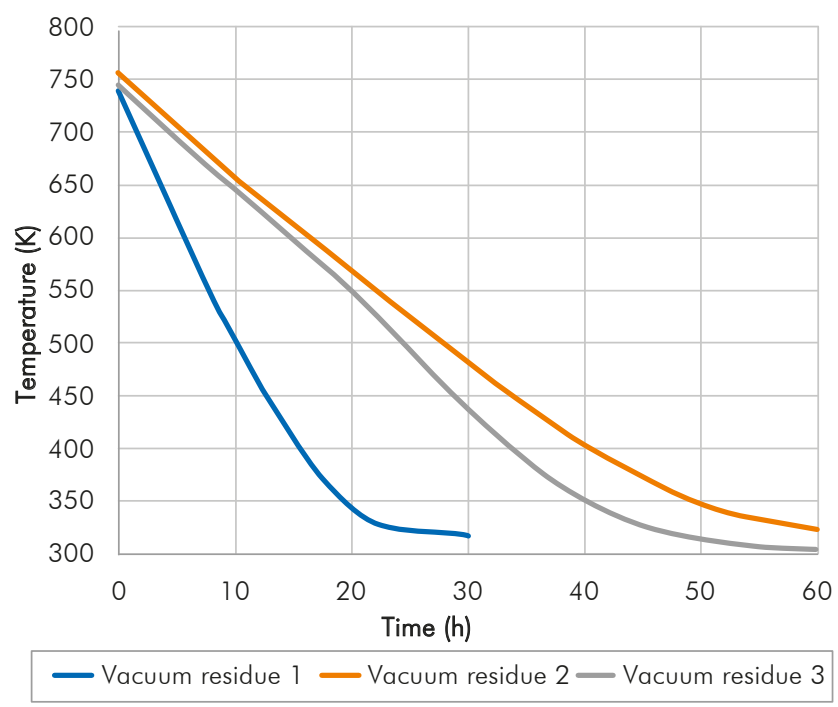

Figure 16. Medium temperature of the coke bed for the three vacuum residue as function of time.

\section{RESULTS ANALYSIS}

Figures 2-4 show how the volume fraction of coke calculated in the simulations is always higher close to the walls of the reactor meaning that there the coke is denser and less porous. Trigo (2005) shows in Figure 17 a coke sample extracted from a delayed coke reactor; it clearly shows how the coke is also denser and less porous close to the walls. This phenomenon occurs because the velocity of the fluids is reduced by the walls and the coke tends to accumulate; this phenomenon is also known in the industry as wall effect.

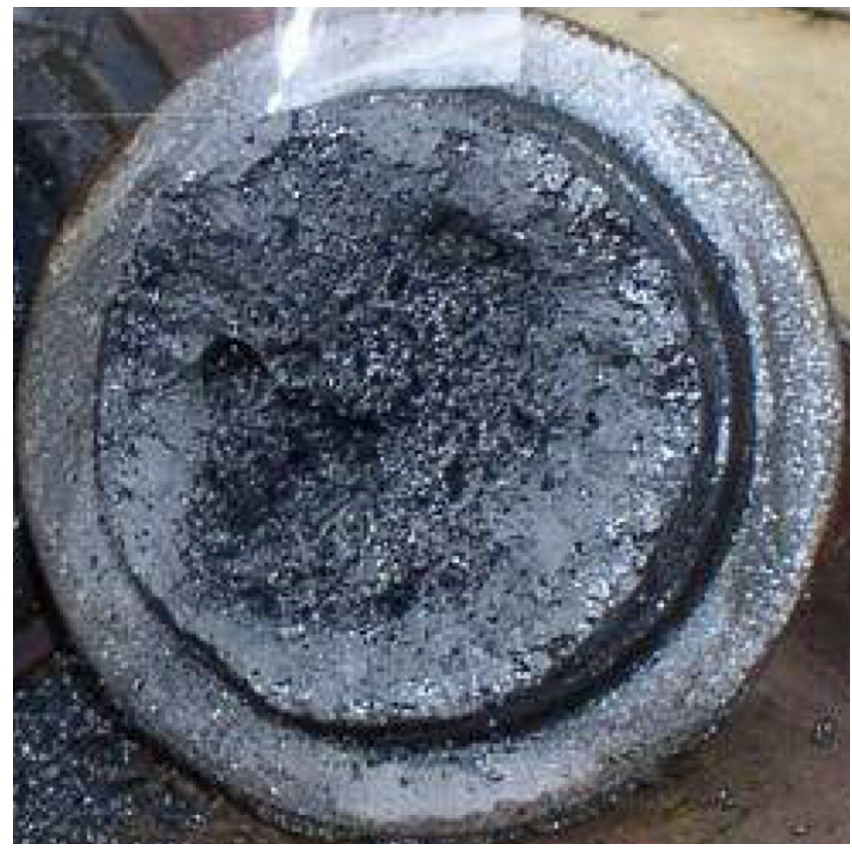

Figure 17. Coke sample extracted from a delayed coking pilot plant, Trigo (2005).

The contours of volume fraction (Figures $2-4$ ) show how the coke bed grows in a homogeneous way and it is always full of vacuum residue and distillables. Figures $5-7$ show how the volume fraction of coke and vacuum residue grow at the same rate, the volume fraction of distillables inside the coke bed is low but above it, there are only distillables, similar to the process for coke formation presented by Ellis \& Hardin (1993).

The contours of temperatures in Figures $2-4$ show very similar temperatures in the three phases, meaning that they can be considered at thermal equilibrium; this occurs mainly due to the small size of the reactor and the small thermal gradients. A higher temperature is also observed in the denser zone of the coke bed due to the lower concentration of fluids dissipating less heat. A reduction of $40-60 \mathrm{~K}$ in the temperature of the upper zone of the coke bed is observed; it occurs due to the higher concentration of distillables dissipating more heat and vacuum residue consuming heat by chemical reaction. A reduction of the temperature at the reactor inlet is also observed, caused by the lower temperature of the feed.

The contours of velocity magnitude on Figures 2 -4 show an increase in the velocity of the distillables through the coke bed, which is expected since the flow 
area has been reduced and the density of the distillables is lower than that of the vacuum residue. Contours of volume fraction show a thin layer of vacuum residue over the surface of the coke bed where a sudden increase in velocity is observed. This phenomenon occurs because the higher velocity of the distillables generates drag over the vacuum residue. It can also be interpreted as a bubbling over the surface of the coke bed.

Table 5 shows a comparison of the weight percentage of coke calculated in the simulations for each vacuum residue with the experimental data provided by ICP. The found maximum percentage of deviation was $4.98 \%$.

Figure 11 shows how the height of the coke bed grows almost linearly for the three vacuum residues, barely a few undulations in the curves are observed. As the reactor feed is constant and steady, the height of the coke bed should grow linearly in time. However some undulations are observed. These are caused by the porosity, which also varies in time and affects the height of the coke bed.
Figures $8-10$ show how the porosity decreases with the height of the coke bed, which means that the bulk density also decreases with height. Volk \& Wisecarver (2005) performed an experiment in a delayed coking pilot plant, and the density of the coke bed obtained was measured by a gamma densitometer at two run times (285 and 345 minutes). Even though the experimental parameters employed by Volk \& Wisecarver (2005) are very different to the ones used in this work, the results of both works can be compared from a qualitative point of view. In Figure 18, the corrected density of the coke bed obtained in the simulation with vacuum residue 1 is compared with the results of Volk \& Wisecarver (2005), and a similar tendency can be observed; a denser coke bed at the bottom and a density that gradually decreases with height. This phenomenon occurs mainly due to the longer reaction time of the coke at the bottom. While the coke at the bottom can take several hours of reaction time, the coke at the top can take some minutes barely. The corrected density is calculated as bulk density over real density.

Figures $8-10$ show how the porosity tends to be uniform at the center of the reactor while at the walls
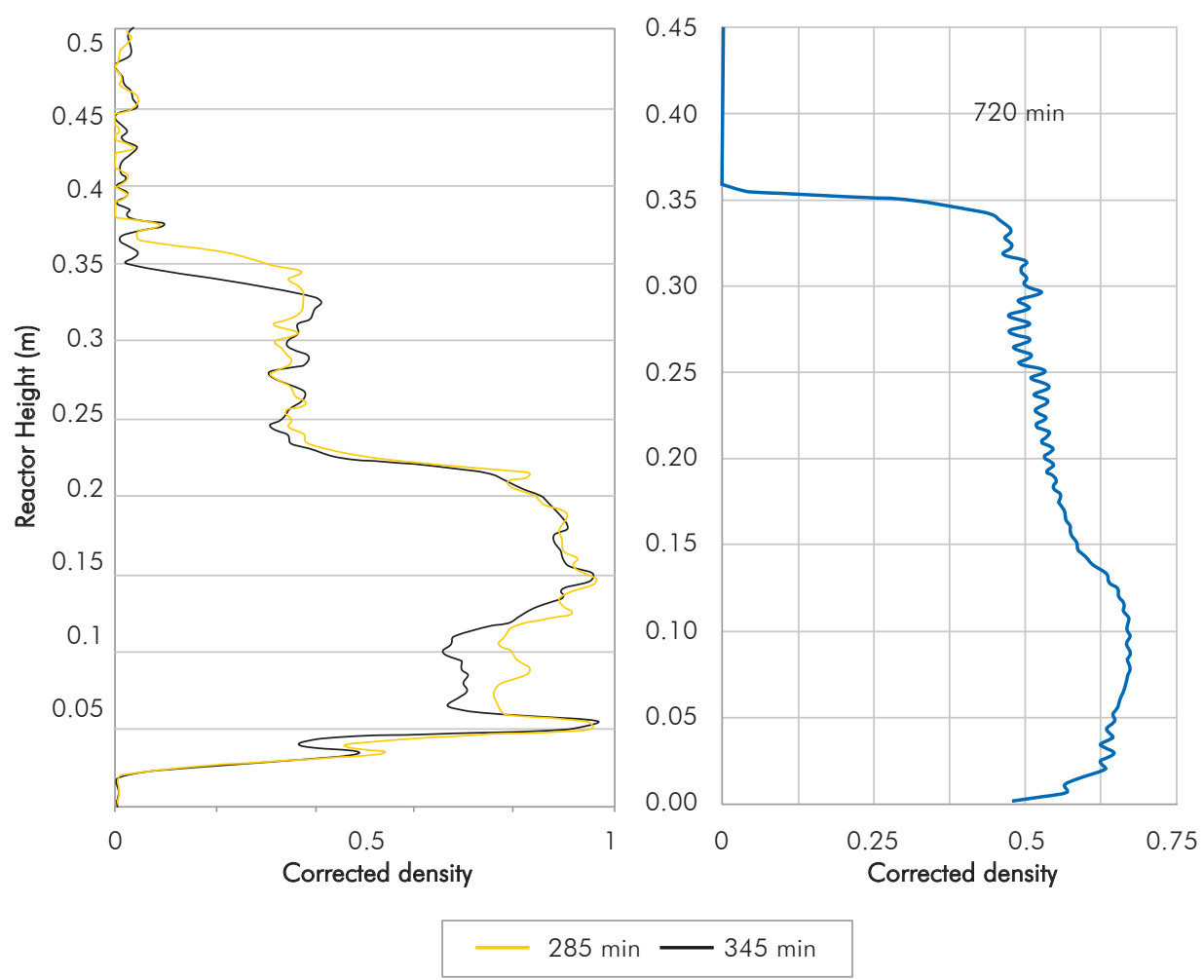

Figure 18. Density of a coke bed measured with a gamma densitometer by Volk \& Wisecarver (2005) (left) vs. density of the coke bed calculated for vacuum residue 1 (right). 
and the bottom, irregular undulations are observed. The porosity of the coke bed is affected by the fluid-dynamic variables of the reaction medium, the contours of volume fraction show a recirculation zone at the bottom of the reactor where most of the undulations are observed.

Table 4 shows that even though vacuum residue 3 generates the higher quantity of coke and the higher coke bed, it does not have the lower porosity. It seems illogical since in this work the porosity has been considered as the space left by the coke volume fraction; therefore, a higher quantity of coke should generate a lower porosity, which did not happen. However, these results confirm observations made by Karacan \& Badger (2003) who affirm that the properties of the coke bed depend on the fluid-dynamic variables of the reaction medium, phenomenon that is reproduced in this work by computational simulation. Figure 19 shows the medium Reynolds number inside the coke bed for the phases vacuum residue, and distillables plotted against the volume-averaged porosity of each coke bed. An apparent linear relationship is observed, where the increase in the Reynolds number generates an increase in the coke bed porosity. Karacan \& Badger (2003) presented similar results experimentally. In their work, the porosity of a coke bed from a delayed coking pilot plant reactor is measured with and without steam injection; the porosity is, evidently, higher with steam injection (increased Reynolds number).

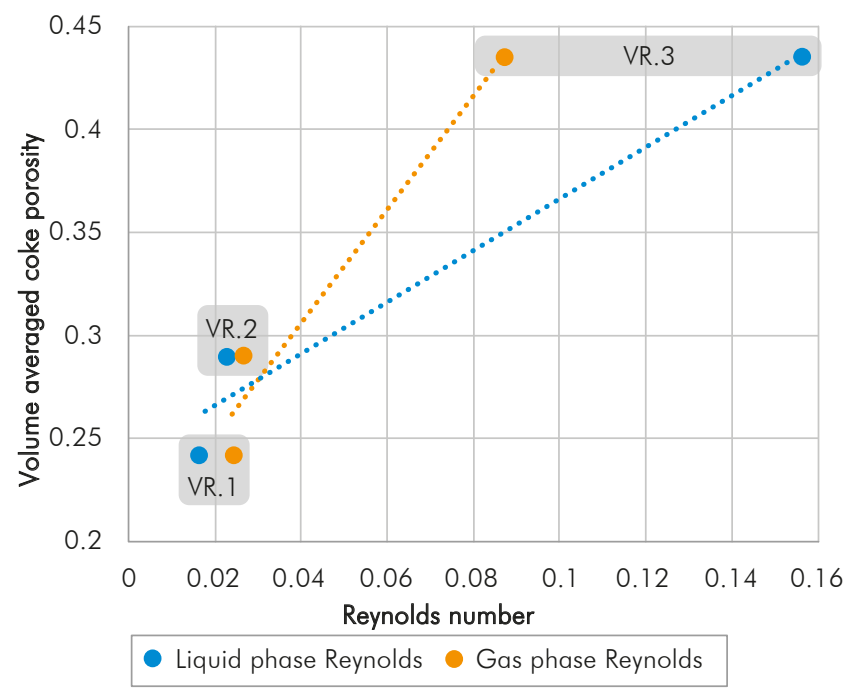

Figure 19. Apparent linear relationship of the liquid and gas phase Reynolds number with the porosity of the coke bed.
The experimental range of cooling time of the coke bed obtained in the pilot plant at ICP goes from 30 to 60 minutes. Even though there is not experimental data to validate the results of the simulation of the coke bed cooling (Figures $13-16$ ), the cooling time estimated in the simulations falls within the experimental range. The coke bed from vacuum residue 1 is the one taking less time to cool down to a temperature of $40^{\circ} \mathrm{C}$ which is expected since it is the smaller and more porous coke bed. The coke bed from vacuum residue 2 took 10 more minutes to cool down than the coke bed from vacuum residue 3 due to the lower porosity (see Table 4), generating less space for the flow of nitrogen and the dissipation of heat.

\section{CONCLUSIONS}

- The CFD simulation of the 12 hours operation run of the delayed coking reactor for the three vacuum residues shows good results, when the weight percentage of coke calculated in the simulations was compared with the experimental data from ICP; the found maximum percentage of deviation was $4.98 \%$.

- The CFD model proposed in this work simulates the formation process of the coke bed and its porosity correctly. When the simulation results are compared with experimental data from the literature, it is found how the simulation reproduces two phenomena that significantly affects the porosity of the coke bed. First, the simulation model reproduces the effect of the reactor walls in the reduction of the porosity of the coke bed. Second, the simulation model also reproduces the increase in the porosity with the height of the coke bed.

- Even though vacuum residue 3 generates the higher quantity of coke and therefore the higher coke bed, it does not have the lowest porosity. In this work, the porosity was considered as the space left by the coke volume fraction. Therefore, a higher quantity of coke should produce a lower porosity, however, this did not occurred. This leads to the conclusion that the porosity does not depend only upon the quantity of coke formed, but also depends upon the fluiddynamic variables of the reaction medium, conclusion that has been exposed previously by Karacan \& 
Badger (2003). When the porosity of the coke bed is compared with the Reynolds number of the liquid and gas phase, an apparent linear relationship is found, where the increase in the Reynolds number generates an increase in the coke bed porosity. Karacan \& Badger (2003) submitted similar results through an experimental work in a delayed coking pilot plant. These results correctly indicate that the simulation model presented in this work simulates the effect of the fluid-dynamic variables of the reaction medium on the formation, accumulation and properties of the coke bed.

\section{ACKNOWLEDGEMENTS}

The authors wish to acknowledge ECOPETROL - ICP for the technical support. The authors also acknowledge Universidad Industrial de Santander and COLCIENCIAS whose financial support was fundamental for the development of this work.

\section{REFERENCES}

ANSYS (2014), ANSYS Fluent 14.0 User Manual, ANSYS Inc.

Borges, C., Mendes, M. \& Alves, R. (2015). Mathematical Modeling of an Industrial Delayed Coking Unit, Computer Aided Chemical Engineering, 37, pp. 515 - 520.

Bozzano, G. \& Dente, M. (2005). A Mechanistic Approach to Delayed Coking Modelling, European Symposium on Computer Aided Process Engineering - 15, 20, pp. $529-534$.

Castiglioni, B. P. (1983). How to Predict Coker Yield, Hydrocarbon Processing, 62(9), pp. 77 - 79.

Diaz, F. A. (2016). Desarrollo de un modelo de simulación para el proceso de coquización retardada de residuos de la refinación de crudos colombianos, Ph.D. Thesis dissertation, Department of Chemical Engineering, Universidad Industrial de Santander, Bucaramanga, Colombia.

Díaz, F. A., Chávez, A., Fuentes, D., Maradei, M., Guzman, A. \& Picón, H. (2015). Kinetic analysis of the thermal decomposition of colombian vacuum residua by thermogravimetry, Ingenieria e investigacion, 35(3), pp. $19-26$.
Ellis, P. \& Hardin, E. (1993). How petroleum delayed coke forms in a drum, Light Metals, pp. $509-515$.

Ergun, S. (1952). Fluid Flow through Packed Columns, Chem. Eng. Prog., 48(2), pp. 89 - 94.

Gary, J. H. \& Handwerk, G. E. (1975). Petroleum Refining - Technology and Economics, Fourth Edition, Marcel Dekker, New York, USA.

Ghashghaee, M. (2015). Predictive correlations for thermal upgrading of petroleum residues, J. Analytical and Applied Pyrolysis, 115, pp. $326-336$.

Karacan, C. \& Badger, M. (2003). Effect of steam injection on pore structure and distribution in coke samples produced by delayed coking. Fuel 82(8), $909-917$.

Li, X., Zhang, R., Suna, Y., Jiang, B., Luo, M., Li, X. \& Zhang, L. (2015). CFD modeling of phase change and coke formation in petroleum refining heaters, Fuel Process. Technol. 134, pp. $18-25$.

Maples, R. E. (2000). Petroleum Refinery Process Economics. Penn Well Publishing Co., Tulsa, USA.

Muñoz, J., Aguilar, R., Castañeda, L. \& Ancheyta, J. (2013). Comparison of Correlations for Estimating Product Yields from Delayed Coking, Energy \& Fuels, 27 (11), pp. 7179 -7190 .

Patankar, S. \& Spalding, D. (1972). A Calculation Procedure for Heat, Mass and Momentum Transfer in Three-Dimensional Parabolic Flows, Int. J. Heat Mass Transfer, 15(10), pp. $1787-1806$.

Pushpalayari, A. G. (2004). Micro-Coker Continuation Studies, M.Sc. Thesis dissertation, Department of Chemical Engineering, University of Tulsa, Tulsa, USA.

Rana, Mohan S., Samano, V., Ancheyta, J. \& Diaz, J.A.I. (2007). A review of recent advances on process technologies for upgrading of heavy oils and residua. Fuel, 86 (9), pp. $1216-1231$.

Souza, B., Matos, E., Guirardello, R. \& Nunhez, J. (2006). Predicting coke formation due to thermal cracking inside tubes of petrochemical fired heaters using a fast CFD formulation, J. Pet. Sci. Eng. 51(1-2), pp. 138 - 148. 
Spalding, D. \& Markatos, N. (1983). Computer Simulation of Multi-Phase Flows: A Course of Lectures and Computer Workshops, Report CFD/83/4, Mech. Eng., Imperial College Sci. Tech., London, UK.

Tian, L., Shen, B. \& Liu, J. (2012a). A delayed coking model built using the structure-oriented lumping method, Energy and Fuels, 26 (3), pp. 1715 - 1724.

Tian, L., Shen, B. \& Liu, J. (2012b). Building and Application of Delayed Coking Structure-Oriented Lumping Model, Ind. Eng. Chem. Res., 51 (10), pp. 3923 - 3931.

Tomiyama, A. (1998). Struggle with computational bubble dynamics. Third International Conference on Multiphase Flow, Lyon, France.

Van Doormal, J. \& Raithby, G. (1984). Enhancements of the SIMPLE Method for Predicting Incompressible Fluid Flows, Numer. Heat Transfer, 7, pp. $147-163$.

Varvitariam, D. \& Andrawis, H. (2006). Delayed coking schemes are most economical for heavy-oil upgrading, Oil \& Gas Journal, 104 (6), pp. $52-56$.

Volk, M., Wisecarver, K. \& Sheppard, C. (2002). Fundamentals of delayed coking joint industry project, Department of chemical engineering, University of Tulsa, Tulsa, USA.

Wakao, N., Kaguei, S. (1982). Heat and Mass Transfer in Packed Beds, Gordon and Breach Science Publishers, New York, USA.

Zambrano, T. A. (2001). Micro-correlations and data analysis, M.Sc. Thesis dissertation, Department of Chemical Engineering, University of Tulsa, Tulsa, USA.

Zhou, X. L., Chen, S. Z. \& Li, C. L. (2007). A predictive kinetic model for delayed coking, Petroleum Science and Technology, 25 (12), pp. $1539-1548$.

\section{AUTHORS}

\section{Fabian Andrey Díaz Mateus}

Affiliation: Escuela de Ingeniería Química, Universidad Industrial

de Santander, Bucaramanga, Colombia.

e-mail: fabiandiazmateus@hotmail.com

\section{Arlex Chaves Guerrero}

Affiliation: Escuela de Ingeniería Química, Universidad Industrial de Santander, Bucaramanga, Colombia.

e-mail: achavesg@uis.edu.co

\section{Paola Gauthier Maradei}

Affiliation: Escuela de Ingeniería Química, Universidad Industrial de Santander, Bucaramanga, Colombia

e-mail:mapaomar@uis.edu.co

\section{David Fuentes}

Affiliation: Escuela de Ingeniería Química, Universidad Industrial de Santander, Bucaramanga, Colombia.

e-mail: dfuentes@uis.edu.co

\section{Alexander Guzmán Monsalve}

Affiliation: Ecopetrol S.A - Instituto Colombiano del Petróleo,

Piedecuesta, Colombia

e-mail: alexander.guzman@ecopetrol.com.co

\section{Hector Julio Picón Hernández}

Affiliation: Ecopetrol S.A - Instituto Colombiano del Petróleo, Piedecuesta, Colombia.

e-mail: Hector.Picon@ecopetrol.com.co 


\section{NOMENCLATURE}

$v \quad$ Velocity vector $(\mathrm{m} / \mathrm{s})$

$t \quad$ Time (s)

$p \quad$ Pressure $(\mathrm{Pa})$

$T \quad$ Temperature (K)

$g \quad$ Gravitational acceleration vector $\left(9.81 \mathrm{~m} / \mathrm{s}^{2}\right)$

$K \quad$ Momentum exchange coefficient

$C p \quad$ Heat capacity $(\mathrm{J} / \mathrm{kg} . \mathrm{K})$

$\Delta \dot{H} \quad$ Heat of reaction $(\mathrm{J} / \mathrm{kg})$

$H \quad$ Heat transfer coefficient $\left(\mathrm{W} / \mathrm{m}^{2} \mathrm{~K}\right)$

$\mu \quad$ Viscosity $(\mathrm{kg} / \mathrm{m} . \mathrm{s})$

CCR Conradson Carbon Residue

Ea Activation energy $(\mathrm{J} / \mathrm{mol})$

$\Delta \mathrm{t} \quad$ Time step size (s)

$\Delta \mathrm{y} \quad$ Cell size in y coordinate $(\mathrm{m})$

a Convection-diffusion coefficient

$\phi \quad$ Random variable

S Source term

$\gamma \quad$ Porosity of the coke bed

$\alpha \quad$ Volume fraction

$\rho \quad$ Density $\left(\mathrm{kg} / \mathrm{m}^{3}\right)$

$\Gamma \quad$ Reaction rate $(1 / \mathrm{s})$

$\mathrm{C}_{2} \quad$ Inertial resistance factor $(1 / \mathrm{m})$

$\varepsilon \quad$ Permeability of the coke bed $\left(\mathrm{m}^{2}\right)$

$k \quad$ Thermal conductivity (W/m.K)

$V R \quad$ Vacuum Residue

$K f \quad$ Frequency factor $(1 / \mathrm{s})$

$\Delta \mathrm{x} \quad$ Cell size in $\mathrm{x}$ coordinate $(\mathrm{m})$

\section{SUBSCRIPTS}

$R \quad$ Vacuum residue phase

$D \quad$ Distillable phase

$C$ Coke phase

$N B \quad$ Neighbor volume

$C V$ Central volume

$n, m \quad$ Vacuum residue or Distillable phase 